\title{
A Time Series of Prehistoric Mitochondrial DNA Reveals Western European Genetic Diversity Was Largely Established by the Bronze Age
}

\author{
François-Xavier Ricaut ${ }^{1 *}$, Murray P. Cox ${ }^{2 *}$, Marie Lacan ${ }^{1,3}$, Christine Keyser ${ }^{3}$, \\ Francis Duranthon ${ }^{1}$, Bertrand Ludes $^{3}$, Jean Guilaine ${ }^{4}$, Eric Crubézy ${ }^{1}$ \\ ${ }^{1}$ Laboratoire d'Anthropologie Moléculaire et Imagerie de Synthèse, Centre National de la Recherche \\ Scientifique, Université de Toulouse (Paul Sabatier), Toulouse, France \\ ${ }^{2}$ Institute of Molecular BioSciences, Massey University, Palmerston North, New Zealand \\ ${ }^{3}$ Laboratoire d'Anthropologie Moléculaire, Centre National de la Recherche Scientifique, Institute of \\ Legal Medicine, University of Strasbourg, Strasbourg, France \\ ${ }^{4}$ Centre de Recherche sur la Préhistoire et la Protohistoire de la Méditerranée, École des Hautes Etudes \\ en Sciences Sociales, Toulouse, France \\ Email: "fx.ricaut@infonie.fr, "m.p.cox@massey.ac.nz \\ Received December $8^{\text {th }}$, 2011; revised January $1^{\text {st }}$, 2012; accepted February $1^{\text {st }}, 2012$
}

\begin{abstract}
A major unanswered question concerns the roles of continuity versus change in prehistoric Europe. For the first time, genetic samples of reasonable size taken at multiple time points are revealing piecemeal snapshots of European prehistory at different dates and places across the continent. Here, we pull these disparate datasets together to illustrate how human genetic variation has changed spatially and temporally in Europe from the Mesolithic through to the present day. Mitochondrial DNA (mtDNA) haplogroups were determined for 532 European individuals from four major eras: the Mesolithic, Neolithic, Chalcolithic (late Neolithic/early Bronze Age transition) and Modern periods. The Mesolithic was characterized by low mtDNA diversity. These initial European settler haplogroups declined rapidly in the Neolithic, as farmers from the east introduced a new suite of mtDNA lineages into Western Europe. For the first time, we show that the Chalcolithic was also a time of substantial genetic change in Europe. However, rather than the arrival of new mtDNA lineages, this period was characterized by major fluctuations in the frequencies of existing haplogroups. Besides the expansion of haplogroup $\mathrm{H}$, there were few major changes in mtDNA diversity from the Chalcolithic to modern times, thus suggesting that the basic profile of modern western European mtDNA diversity was largely established by the Bronze Age.
\end{abstract}

Keywords: Europe; Prehistory; MtDNA; Haplogroup Diversity; Temporal Dynamics

\section{Introduction}

Modern European genetic diversity is increasingly well characterized. Researchers have detailed the geographic distribution of maternal (mtDNA) and paternal (Y chromosome) lineages, and are now delving into the spatial distribution of autosomal variants. European individuals can be assigned to modern nations, and even in particular cases, to areas as small as villages (Novembre et al., 2008). Yet how this genetic diversity has changed through time is much less well understood. Precise real-time information is largely restricted by advances in ancient DNA research, a growing but challenging field. Nevertheless, samples of reasonable size taken at multiple time points are now starting to provide snapshots of genetic variation during European prehistory at different times and places across the continent. It therefore seems timely to attempt a first pass at describing how human genetic variation has changed spatially and temporally in Europe from the Stone Age through to the present day.

A major unanswered question concerns the roles of continuity versus change in prehistoric Europe. For instance, the main drivers of the agricultural expansion have long been a topic of

\footnotetext{
"Corresponding author.
}

considerable debate. What originally was perceived as a simple distinction between demic versus cultural diffusion is now generally recognized as a more complex set of processes. These processes produced broad-scale demographic trends, while still allowing mosaic regional patterns (e.g., Ammerman \& CavalliSforza, 1984; Whittle, 1996; Whittle \& Cummings, 2007). This more nuanced view emphasizes cultural and population dispersals, as well as variable patterns of population admixture, where the relative biological contributions of Near Eastern Neolithic farmers and indigenous Mesolithic hunter-gatherers are not distributed uniformly across Europe (Sampietro et al., 2007; Bramanti et al., 2009; von Cramon-Taubadel \& Pinhasi, 2011). Current understanding emphasizes two different migration routes; a relatively rapid diffusion via a southern route along the Mediterranean coast (associated with the Impressed Ware and Cardial Ware culture), together with a slower northern route along the Danube valley into central Europe (associated with the Linearbandkeramik, or LBK, culture) (Guilaine, 1997, 2003; Gronenborn, 1999; Zvelebil, 2004; Guilaine \& Manen, 2007). Mosaic models such as these emphasize the complex processes by which the transition to agriculture in Europe probably took place, simultaneously explaining the seemingly conflicting results obtained from archaeological evidence (e.g., Guilaine, 2003; Bar-Yosef, 2004; Pinhasi et al., 
2005; Bailey \& Spikins, 2008; Bocquet-Appel et al, 2009; Rowley-Conwy, 2011), osteological data (e.g., Crubézy et al., 2002; Pinhasi \& von Cramon-Taubadel, 2009; von CramonTaubadel \& Pinhasi, 2011), modern genetic analyses (e.g., Cavalli-Sforza et al., 1994; Chikhi et al., 1998; Renfrew \& Boyle, 2000; Bellwood \& Renfrew, 2002; Richards, 2003; Belle et al., 2006; Balaresque et al, 2010; Palanichamy et al., 2010; Soares et al., 2010) and ancient DNA studies (e.g., Haak et al., 2005, 2010; Sampietro et al., 2007; Bramanti et al., 2009; Malmström et al., 2009; Lacan et al., 2011).

Although considerable research has been focused on the spread of agriculture through Europe (as evidenced by the large number of studies cited above), the periods immediately prior to, and following, the agricultural revolution have been explored in far less detail. In this context, three subject areas would seem to warrant further examination:

1) Ancient southwestern/Mediterranean biological data are typically underrepresented, mainly due to bone preservation issues outside the colder/temperate climate regions of the north. Extant research has typically focused on ancient northern or central European populations (Haak et al., 2005, 2010; Bramanti et al., 2009; Pinhasi \& von Cramon-Taubadel 2009; von Cramon-Taubadel \& Pinhasi 2011). Few studies have analyzed and compared ancient biological data from multiple sites or regions across Europe.

2) The effects of cultural differences on genetic diversity between southern and northern Europe through the Neolithic and Chalcolithic periods have not been addressed. This time frame saw two contrasting Neolithic cultures in Europe (Linearbandkeramik in central Europe and the Impressed/Cardial Ware culture in southern Europe), each seemingly linked to a different Chalcolithic subsistence strategy (a cattle-based, fresh milk dairying economy in northern Europe, and agropastoral cultures based on preserved milk sheep/goat farming in southern Europe) (Itan et al., 2009). The role of genetic connections between these two regions and cultures remains unclear.

3) Little is known about changes in genetic diversity during the important post-Neolithic transitional period. In addition to the Mesolithic/Neolithic transition, the Chalcolithic period also witnessed substantial culture change, particularly in terms of the adoption of metal tools, new agricultural techniques (yoke and ard-plough), means of transport (wheeled vehicles) and emerging long-distance exchange networks (Sherratt 1981).
These important cultural processes had the potential for major demographic impacts on European populations.

While studies of nuclear DNA still involve extremely small numbers of individuals (Burger et al., 2007; Haak et al., 2008, 2010; Malmström et al., 2009; Lacan et al., 2011) and are not considered further here, the accumulation of mtDNA sequences from ancient European individuals is increasing rapidly. We now have mtDNA data for $>100$ individuals from the Mesolithic period (more than $\sim 9000$ years before present), the Neolithic period (the samples in this study are from the early Neolithic, 9000 - 5500 years before present) and the Chalcolithic period (the transition from the late Neolithic to the early Bronze Age, 5500 - 3700 years before present).

This dataset, while still modest, is an extraordinary achievement, and at last provides a test bed to explore simple demographic scenarios that begin to move our perspective of European genetic prehistory beyond intra-site/intra-region analyses. Using these ancient mtDNA sequences, we interrogate haplogroup frequency distributions to resolve through-time biological relationships between two different regions in western Europe (southern and northern), four different time points (Mesolithic, Neolithic, Chalcolithic and the Modern era), and two different cultural traditions (Linearbandkeramik versus the Impressed/Cardial Ware culture). To our knowledge, this is the first extended analysis of spatial and temporal genetic continuity through European prehistory.

\section{Methods}

\section{Samples}

Mitochondrial DNA haplogroup classifications were determined for 532 European individuals from four major eras: the Mesolithic, Neolithic, Chalcolithic and Modern periods (Table 1). This dataset includes 109 ancient samples, representing 15 individuals from the Mesolithic period (Bramanti et al., 2009), 56 individuals from the Neolithic (Haak et al., 2005, 2010; Haak, 2006; Sampietro et al., 2007; Deguilloux et al., 2011), and 38 individuals from the Chalcolithic (Itan et al., 2009; Haak et al., 2008). The Mesolithic dataset analyzed here specifically excludes Mesolithic communities in close proximity to Neolithic sites, because these samples are potentially affected by gene flow from neighboring Neolithic peoples (Bramanti

Table 1.

Population samples used in this study.

\begin{tabular}{|c|c|c|c|c|c|c|}
\hline Period & Geographic Area & Location & Dates & $\mathrm{n}$ & Culture & Reference \\
\hline Mesolithic & Central/North & $\begin{array}{l}\text { Germany, Russia, } \\
\text { Poland, Lithuania }\end{array}$ & $13,400-2250 \mathrm{BC}$ & 15 & $\begin{array}{c}\text { Kunda, Narva, } \\
\text { Zedmar, Beuronien }\end{array}$ & Bramanti et al., 2009 \\
\hline \multirow[t]{3}{*}{ Neolithic } & Central/North & $\begin{array}{l}\text { Austria, Hungary, } \\
\text { Germany, }\end{array}$ & $5500-5000$ BC & 47 & Linearbandkeramik (LBK) & Haak et al., 2005; Haak, 2006 \\
\hline & Southwestern & Spain & $3500-3000$ BC & 11 & ND & Sampietro et al., 2007 \\
\hline & Southwestern & France & $4200 \mathrm{BC}$ & 3 & Megalithic & Deguilloux et al., 2011 \\
\hline \multirow[t]{2}{*}{ Chalcolithic } & Central/North & Germany & $2700-2400 \mathrm{BC}$ & 9 & Corded Ware Culture (CWC) & Haak et al., 2008 \\
\hline & Southwestern & France & $3030-2890$ BC & 29 & ND & Lacan et al., 2011 \\
\hline \multirow[t]{2}{*}{ Modern } & Central/North & Germany & $2000 \mathrm{AD}$ & 213 & - & Tetzlaff et al., 2007 \\
\hline & Southwestern & France & $2000 \mathrm{AD}$ & 210 & - & Dubut et al., 2004 \\
\hline
\end{tabular}

Abbreviations: n, number of samples; NS, not determined. 
et al., 2009). For purposes of comparison, we also included 423 modern Europeans from locations near the ancient DNA sampling sites (Dubut et al., 2004; Tetzlaff et al., 2007).

Despite the few ancient DNA datasets available, we purposely excluded any data from studies where any doubts have been raised about ancient DNA reliability, unclear sample provenance, uncertain dating or cultural affiliation (particularly during the Mesolithic), or sites that fall outside the geographic range under study here (i.e., essentially central/western Europe) (Izagirre \& de la Rúa, 1999; Di Benedetto et al., 2000; Chandler et al., 2005; Fernández Domínguez, 2005; Ermini et al., 2008; Bramanti et al., 2009; Malmström et al., 2009).

\section{Mitochondrial DNA Haplogroups}

The ancient and modern samples were clustered into 24 haplogroups, 7 of which are found only in individuals living today (Table 2). We used the same haplogroup affiliations as determined in the original studies wherever possible. These were checked manually against the sequence data. Due to the small number of individuals carrying some lineages, related subhaplogroups were sometimes clustered into their root-haplogroup to provide sufficient power for the following analyses.

Table 2.

Observed mtDNA haplogroup frequencies across the Mesolithic, Neolithic, Chalcolithic and Modern periods.

\begin{tabular}{|c|c|c|c|c|}
\hline \multirow{2}{*}{$\mathrm{Hg}$} & \multicolumn{4}{|c|}{ Time Period } \\
\hline & Mesolithic & Neolithic & Chalcolithic & Modern \\
\hline $\mathrm{U}^{*}$ & 0.133 & 0 & 0.026 & 0.014 \\
\hline U2 & 0 & 0 & 0 & 0.014 \\
\hline U3 & 0 & 0.016 & 0 & 0.002 \\
\hline U4 & 0.133 & 0.033 & 0 & 0.033 \\
\hline U5 & 0 & 0 & 0.105 & 0.007 \\
\hline U5a & 0.267 & 0.033 & 0 & 0.059 \\
\hline U5b & 0.467 & 0.016 & 0.053 & 0.024 \\
\hline U6a1 & 0 & 0 & 0 & 0.005 \\
\hline U7 & 0 & 0 & 0 & 0.002 \\
\hline U8 & 0 & 0 & 0 & 0.007 \\
\hline $\mathrm{HV}$ & 0 & 0.066 & 0.079 & 0.047 \\
\hline $\mathrm{H}$ & 0 & 0.230 & 0.184 & 0.423 \\
\hline $\mathrm{N}$ & 0 & 0.131 & 0 & 0.005 \\
\hline $\mathrm{K}$ & 0 & 0.098 & 0.158 & 0.090 \\
\hline $\mathrm{T}$ & 0 & 0.033 & 0 & 0.026 \\
\hline $\mathrm{T} 1$ & 0 & 0 & 0 & 0.028 \\
\hline $\mathrm{T} 2$ & 0 & 0.164 & 0.053 & 0.064 \\
\hline T3 & 0 & 0 & 0 & 0.002 \\
\hline $\mathrm{J}$ & 0 & 0.033 & 0 & 0.014 \\
\hline $\mathrm{J} 1$ & 0 & 0.082 & 0.158 & 0.047 \\
\hline $\mathrm{J} 2$ & 0 & 0 & 0 & 0.012 \\
\hline I & 0 & 0.016 & 0.026 & 0.021 \\
\hline W & 0 & 0.033 & 0 & 0.024 \\
\hline $\mathrm{X}$ & 0 & 0.016 & 0.158 & 0.012 \\
\hline ND & 0 & 0 & 0 & 0.017 \\
\hline
\end{tabular}

Abbreviations: Hg, haplogroup; ND, not determined.

\section{Statistics}

Differences in haplogroup frequencies between temporally separated European populations were determined using an inhouse resampling algorithm implemented in R (http://www. r-project.org/) (code available on request). The frequency probability density was inferred for each haplogroup via Monte Carlo simulation. Because sample sizes are small, ancient haplogroup frequencies typically have large uncertainty. The frequency probability density explicitly accounts for this uncertainty. For each haplogroup, the observed frequency in the younger sample was compared with the frequency probability density of the older sample. This process yields the probability of the younger sample frequency being observed given uncertainty around the ancestral sample frequency. In effect, we asked whether time-adjacent haplogroup frequencies differ significantly, and therefore, whether haplogroup frequencies have changed between older and younger samples; or whether haplogroup frequencies are statistically indistinguishable, and therefore, show no evidence of change between adjacent time points. We emphasize that this statistical approach explicitly accounts for small sample sizes, even when these are extremely limited (e.g., Eulau). Smaller sample sizes are merely reflected by larger confidence intervals. All population comparisons were performed in natural time order: Modern deriving from Chalcolithic, Chalcolithic deriving from Neolithic, and Neolithic deriving from Mesolithic.

\section{Results}

We explored mtDNA haplogroup frequencies in 532 western European individuals from four different time points: the Mesolithic, Neolithic, Chalcolithic and Modern periods. Individuals carrying 24 different haplogroups were identified (Table 2). Notably, however, the distribution of these haplogroups (supplemental Tables 1-4) changed markedly across the four sampled time points (Figure 1).
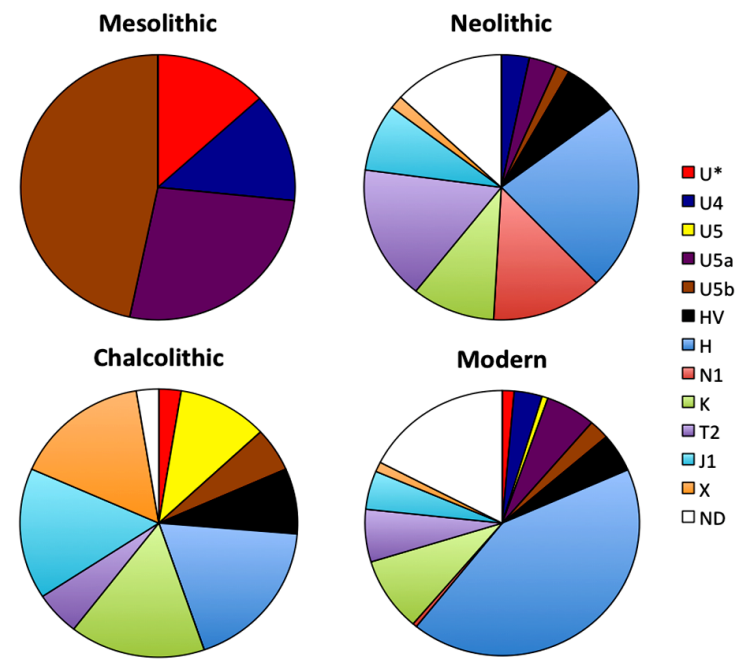

Figure 1.

Pie charts showing mtDNA haplogroup frequencies through time. For visual clarity, haplogroups with frequencies $<5 \%$ across all four samples have been collapsed into a "not determined" category. (Also see supplemental Movie 1, which illustrates dynamically how mtDNA haplogroup frequencies have changed through the four sampled time points). 


\section{The Mesolithic/Neolithic Transition}

This time period is characterized by substantial change, with significant reductions in many of the $U$ haplogroups ( $U^{*}, U 4$, U5a and U5b), together with the sudden appearance of several new haplogroups, including $\mathrm{H}, \mathrm{HV}, \mathrm{I}, \mathrm{J}, \mathrm{J} 1, \mathrm{~K}, \mathrm{~N} 1, \mathrm{~T}, \mathrm{~T} 2, \mathrm{~W}$ and $X$. The small size of the Mesolithic sample $(n=15)$ greatly reduces the statistical power of this analysis. Therefore, with the exception of haplogroup $\mathrm{H}$, the sudden appearance of non$\mathrm{U}$ haplogroups is not statistically significant in our analysis. However, we anticipate that the sudden arrival of these haplogroups will be recognized as significant as additional typing increases the Mesolithic sample size and overcomes the low power of the current dataset. Indeed, while several U haplogroups (i.e., U*, U4, U5 and U8) are traditionally associated with the Upper Paleolithic settlement of Europe, many non-U haplogroups are thought to reflect later phases of population migration and colonization (Richards et al., 2000; Bramanti et al., 2009; Malyarchuk et al., 2010; Soares et al., 2010). We anticipate that future sampling will increase the resolution of this important phase in European prehistory.

\section{The Neolithic/Bronze Age or Chalcolithic Transition}

This time period is much less well studied than the agricultural revolution. Surprisingly, we also observe considerable change in haplogroup frequencies in the lead up to the Chalcolithic period, with significant increases in U5 and X, and statistically significant decreases in U3, U4, U5a, J, N1, T, T2 and W. While the Neolithic has long been recognized as a period of substantial immigration and population change, the transition to the Bronze Age is usually considered more of an indigenous affair. However, our analysis illustrates that the Chalcolithic transition was, from the perspective of haplogroup frequencies, at least as demographically disruptive as the earlier agricultural revolution.

\section{The Chalcolithic/Modern Transition}

Conversely, there is little evidence of change in haplogroup frequencies between the Chalcolithic and Modern periods. The only statistically significant differences are reductions in U5, J1 and $\mathrm{X}$, and a substantial increase in haplogroup $\mathrm{H}$, which at a frequency of $42 \%$, dominates the western European mtDNA gene pool today.

MtDNA haplogroup frequencies at these four time points are illustrated in Figure 1. However, static images like these cannot easily capture how haplogroup frequencies have changed through time. In practice, it is likely that haplogroup frequentcies often changed quickly due to short, intense periods of migration and social upheaval, rather than varying regularly through time. Nevertheless, we can see important dynamic facets of the data, including the extensive diversification of mtDNA haplogroups between the Mesolithic and the Neolithic, and the increasing dominance of haplogroup $\mathrm{H}$ from the Chalcolithic to modern times.

\section{Discussion}

This temporal analysis suggests that two of the three transitional periods (Mesolithic/Neolithic and Neolithic/Bronze Age) saw substantial change in the distribution of European mtDNA haplogroup diversity. However, these changes likely had dif- ferent proximate causes. During the Mesolithic/Neolithic transition, the appearance of new mtDNA haplogroups may have been caused in part by the post-glacial recolonization of Europe (e.g., H, K and T2) and/or by the expansion of Neolithic farmers from the east (e.g., J2, N1 and T2). In either case, there seems little doubt that Europe experienced some degree of gene flow during this time period (Haak et al., 2010; Soares et al., 2010). Conversely, the Chalcolithic transition (late Neolithic to early Bronze Age transition) seems to reflect continuity of existing lineages rather than the appearance of new ones; few new haplogroups are observed in the Chalcolithic, but many existing haplogroups underwent substantial changes in allele frequency. Finally, there is surprisingly little change in haplogroup diversity from the Chalcolithic to the Modern period. While haplogroup frequencies altered substantially during the Neolithic, they began to stabilize during the Chalcolithic and have remained relatively static ever since.

These general patterns hold true when the analysis is repeated at regional scales; e.g., diachronic analyses for southern Europe (essentially modern France, supplemental Table 2) and northern Europe (essentially modern Germany, supplemental Table 3). The main distinction being that there is little difference between Neolithic and Chalcolithic samples in the south, while Neolithic and Chalcolithic populations are quite different in the north. Conversely, three haplogroups (U5b, I and X) have similar frequencies between the southern Neolithic sample and the northern Chalcolithic sample (supplemental Table 4). The northern Chalcolithic sample (Eulau, $n=9$ ) is extremely small, which may accentuate this difference. We note, however, that the statistical procedure used here explicitly accounts for small sample sizes. No haplogroups have similar frequencies between the northern Neolithic and northern Chalcolithic samples (supplemental Table 3). We would not place too much weight on this observed pattern given limitations of the available data. However, this may indicate relatively more continuity between the southern Neolithic and northern Chalcolithic populations (i.e., a signal of northward gene flow). This would agree with some hypotheses regarding the northward spread of the Bell Beaker culture during the late Neolithic/early Chalcolithic (Vander Linden, 2007; Guilaine et al., 2011), particularly since Eulau is one of the few sites where both cultures (Bell Beaker and Corded Ware) existed side by side (Haak et al., 2008).

\section{Conclusion}

This statistical analysis highlights both continuity and change in mtDNA diversity through western European prehistory. As new samples become available, we expect that this first diachronic synthesis of mtDNA change in Western Europe will rapidly be improved upon. Broader geographical sampling will fill in regional details, including the effects of spatially and temporally restricted cultural processes, and will likely highlight more detailed regional variability. Further, we anticipate that technological advances will soon expand this story, moving it from solely a maternal perspective to instead capture paternal and biparental aspects of European genetic prehistory. For now, however, the main story is this. The Mesolithic period was characterized by low mtDNA diversity, entirely dominated by $U$ haplogroups. The Neolithic saw the start of an ongoing decline in these haplogroups, as farmers from the east introduced a suite of new mtDNA haplogroups into Western Europe. 
Although not previously appreciated, the Chalcolithic (late Neolithic to early Bronze Age transition) was also a time of substantial genetic change, which did more to shape current mtDNA diversity than any subsequent time periods. However, rather than the arrival of new mtDNA lineages, the Chalcolithic is characterized by major fluctuations in the frequencies of existing haplogroups. During this period, southern Europe experienced regional continuity, although there may be evidence of northward population movements as the Neolithic gave way to the Chalcolithic. Apart from the ongoing expansion of haplogroup $\mathrm{H}$, there were few major changes from the Chalcolithic period to modern times, and it appears that the basic profile of modern western European mtDNA diversity was largely established by the Bronze Age. In this context, the well-documented narratives of the historic period seem to have played out on a background of European genetic diversity that was ultimately laid down thousands of years earlier.

\section{Acknowledgements}

This research was supported by grants from the French Department of Research and the CNRS-département INNE to F.X.R., and a Rutherford Fellowship awarded to M.P.C. by the Royal Society of New Zealand (RDF-10-MAU-001). We are grateful to Patrice Gerard and Rebecca Coles for constructive comments on the manuscript.

\section{REFERENCES}

Ammerman, A. J., \& Cavalli-Sforza, L. L. (1984). The neolithic transition and the genetics of populations in Europe. Princeton, NJ: Princeton University Press.

Bailey, G., \& Spikins, P. (2008). Mesolithic Europe. Cambridge: Cambridge University Press.

Balaresque, P., Bowden, G. R., Adams, S. M., Leung, H. Y., King, T.E., Rosser, Z. H., Goodwin, J., Moisan, J. P., Richard, C., Millward, A., Demaine, A. G., Barbujani, G., Previdere, C., Wilson, I. J., TylerSmith, C., \& Jobling, M. A. (2010). A predominantly Neolithic origin for European paternal lineages. PLoS Biology, 8, e1000285. doi:10.1371/journal.pbio.1000285

Bar-Yosef, O. (2004). East to west: Agricultural origins and dispersal into Europe. Current Anthropology, 45, S1-S3. doi:10.1086/423970 doi:10.1086/423970

Belle, E. M., Landry, P. A., \& Barbujani, G. (2006). Origins and evolution of the Europeans' genome: Evidence from multiple microsatellite loci. Proceedings of the Royal Society B, 273, 1595-1602. doi:10.1098/rspb.2006.3494

Bellwood, R., \& Renfrew, C. (2002). Examining the farming/language dispersal hypothesis. Cambridge: McDonald Institute for Archaeological Research.

Bramanti, B., Thomas, M. G., Haak, W., Unterlaender, M., Jores, P., Tambets, K., Antanaitis-Jacobs, I., Haidle, M. N., Jankauskas, R., Kind, C. J., Lueth, F., Terberger, T., Hiller, J., Matsumura, S., \& Forster, P. (2009). Genetic discontinuity between local hunter-gatherers and central Europe’s first farmers. Science, 326, 137-140. doi:10.1126/science.1176869

Bocquet-Appel, J. P., Naji, S., Vander Linden, M., \& Kozlowski, J. K. (2009). Detection of diffusion and contact zones of early farming in Europe from the space-time distribution of 14C dates. Journal of Archaeological Science, 36, 807-820. doi:10.1016/j.jas.2008.11.004

Burger, J., Kirchner, M., Bramanti, B., Haak, W., \& Thomas, M. G. (2007). Absence of the lactase-persistence-associated allele in early Neolithic Europeans. Proceedings of the National Academy of Sciences USA, 104, 3736-3741. doi:10.1073/pnas.0607187104

Cavalli-Sforza, L. L., Menozzi, P., \& Piazza, A. (1994). The history and geography of human genes. Princeton, NJ: Princeton University
Press.

Chandler, H., Sykes, B., \& Zilhão, J. (2005). Using ancient DNA to examine genetic continuity at the Mesolithic-Neolithic transition in Portugal. In P. Arias, R. Ontanon, \& A. Garcia-Monco (eds.), Actas del III Congreso del Neolitico en la Peninsula Iberica, 781-786.

Chikhi, L., Destro-Bisol, G., Bertorelle, G., Pascali, V, \& Barbujani, G. (1998). Clines of nuclear DNA markers suggest a largely Neolithic ancestry of the European gene pool. Proceedings of the National Academy of Sciences USA, 95, 9053-9058. doi:10.1073/pnas.95.15.9053

Crubézy, E., Bruzek, J., \& Guilaine, J. (2002). The transition to agriculture in Europe: An anthropobiological perspective. Biennial Book of the European Anthropological Association, 2, 93-110.

Deguilloux, M. F., Soler, L., Pemonge, M. H., Scarre, C., Joussaume, R., \& Laporte, L. (2011). News from the west: Ancient DNA from a French megalithic burial chamber. American Journal of Physical Anthropology, 144, 108-118. doi:10.1002/ajpa.21376

Di Benedetto, G., Nasidze, I.S., Stenico, M., Nigro, L., Krings, M., Lanzinger, M., Vigilant, L., Stoneking, M., Pääbo, S., \& Barbujani, G. (2000). Mitochondrial DNA sequences in prehistoric human remains from the Alps. European Journal of Human Genetics, 8, 669677. doi:10.1038/sj.ejhg.5200514

Dubut, V., Chollet, L., Murail, P., Cartault, F., Béraud-Colomb, E., Serre, M., \& Mogentale-Profizi, N. (2004). MtDNA polymorphisms in five French groups: Importance of regional sampling. European Journal of Human Genetics, 12, 293-300. doi:10.1038/sj.ejhg.5201145

Ermini, L., Olivieri, C., Rizzi, E., Corti, G., Bonnal, R., Soares, P., Luciani, S., Marota, I., De Bellis, G., Richards, M.B., \& Rollo, F. (2008). The complete mitochondrial genome sequence of the Tyrolean Iceman. Current Biology, 18, 1687-1693. doi:10.1016/j.cub.2008.09.028

Fernández Domínguez, E. (2005). Polimorfismos de DNA mitocondrial en poblaciones antiguas de la cuenca mediterránea. Ph.D. Thesis, Barcelona: University of Barcelona.

Gronenborn, D. (1999). A variation on the basic theme: The transition to farming in southern central Europe. Journal of World Prehistory, 2, 123-210. doi:10.1023/A:1022374312372

Guilaine, J. (1997). Résumé des Cours et travaux 1996-1997. Paris: Collège de France.

Guilaine, J. (2003). De la Vague à la tombe. la conquête néolithique de la méditerranée (8000-2000 av. JC). Paris: Seuil Press.

Guilaine, J., \& Manen, C. (2007). From Mesolithic to early Neolithic in the western Mediterranean. In A. Whittle, \& V. Cummings (eds.), Going over: The mesolithic-neolithic transition in north-west Europe (pp. 21-51). London: Proceedings of the British Academy.

Guilaine, J., Tusa, S., \& Veneroso, P. (2011). La Sicile et l'Europe Campaniforme. Toulouse: Archives d'Ecologie Prehistorique.

Haak, W. (2006). Populationsgenetik der ersten Bauern Mitteleuropas. Eine aDNA-Studie an neolithischem Skelettmaterial. Ph.D. Thesis, Mainz: University of Mainz.

Haak, W., Balanovsky, O., Sanchez, J. J., Koshel, S., Zaporozhchenko, V., Adler, C. J., Der Sarkissian, C. S., Brandt, G., Schwarz, C., Nicklisch, N., Dresely, V., Fritsch, B., Balanovska, E., Villems, R., Meller, H., Alt, K. W., Cooper, A., \& the Genographic Consortium. (2010). Ancient DNA from European early Neolithic farmers reveals their near eastern affinities. PLoS Biology, 9, e1000536. doi:10.1371/journal.pbio.1000536

Haak, W., Brandt, G., de Jong, H. N., Meyer, C., Ganslmeier, R., Heyd, V., Hawkesworth, C., Pike, A. W., Meller, H., \& Alt, K. W. (2008). Ancient DNA, strontium isotopes, and osteological analysis shed light on social and kinship organization of the Later Stone Age. Proceedings of the National Academy of Sciences USA, 105, 1822618231. doi:10.1073/pnas.0807592105

Haak, W., Forster, P., Bramanti, B., Matsumura, S., Brandt, G., Tanzer, M., Villems, R., Renfrew, C., Gronenborn, D., Alt, K. W., \& Burger, J. (2005). Ancient DNA from the first European farmers in 7500year-old Neolithic sites. Science, 310, 1016-1018.

Itan, Y., Powell, A., Beaumont, M. A., Burger, J., \& Thomas, M. G. (2009). The origins of lactase persistence in Europe. PLoS Computa- 
tional Biology, 5, e1000491. doi:10.1371/journal.pcbi.1000491

Izagirre, N., \& de la Rúa, C. (1999). Absence of mtDNA haplogroup V in ancient Basques, American Journal of Human Genetics, 65, 199-207. doi:10.1086/302442

Lacan, M., Keyser, C., Ricaut, F. X., Brucato, N., Duranthon, F., Guilaine, J., Crubézy, E., \& Ludes, B. (2011). Ancient DNA revealed male diffusion through the Neolithic Mediterranean route. Proceedings of the National Academy of Sciences USA, 108, 9788-9791. doi:10.1073/pnas.1100723108

Malmström, H., Gilbert, M. T. P., Thomas, M. G., Branström, M., Stora, J., Molnar, P., Andersen, P. K., Bendixen, C., Holmlund, G., Götherström, A., Willerslev, E. (2009). Ancient DNA reveals lack of continuity between Neolithic hunter-gatherers and contemporary Scandinavians. Current Biology, 19, 1758-1762. doi:10.1016/j.cub.2009.09.017

Malyarchuk, B., Derenko, M., Grzybowski, T., Perkova, M., Rogalla, U., Vanecek, T., \& Tsybovsky, I. (2010). The peopling of Europe from the mitochondrial haplogroup U5 perspective. PLOS ONE, 5, e10285. doi:10.1371/journal.pone.0010285

Novembre, J., Johnson, T., Bryc, K., Kutalik, Z., Boyko, A. R., Auton, A., Indap, A., King, K. S., Bergmann, S., Nelson, M. R., Stephens, M., \& Bustamante, C. D. (2008). Genes mirror geography within Europe. Nature, 456, 98-101. doi:10.1038/nature07331

Palanichamy, M. G., Zhang, C. L., Mitra, B., Malyarchuk, B., Derenko, M., Chaudhuri, T. K., \& Zhang, Y. P. (2010). Mitochondrial haplogroup N1a phylogeography, with implication to the origin of European farmers. BMC Evolutionary Biology, 10, 304. doi:10.1186/1471-2148-10-304

Pinhasi, R., Fort, J., \& Ammerman, A. J. (2005). Tracing the origin and spread of agriculture in Europe. PLoS Biology, 3, e410. doi:10.1371/journal.pbio.0030410

Pinhasi, R., \& von Cramon-Taubadel, N. (2009). Craniometric data supports demic diffusion model for the spread of agriculture into Europe. PLOS ONE, 4, e6747. doi:10.1371/journal.pone.0006747

Renfrew, C., \& Boyle, K. (2000). Archaeogenetics: DNA and the population prehistory of Europe. Cambridge: McDonald Institute for Archaeological Research.

Richards, M. (2003). The Neolithic invasion of Europe. Annual Review of Anthropology, 32, 135-162. doi:10.1146/annurev.anthro.32.061002.093207

Richards, M. V., Macauley, V., Hickey, E., Vega, E., Sykes, B., Guida, V., Rengo, C., Sellitto, D., Cruciani, F., Kivisild, T., Villems, R., Thomas, M., Rychkov, S., Rychkov, O., Rychkov, Y., Gölge, M.,
Dimitrov, D., Hill, E., Bradley, D., Romano, V., Calì, F., Vona, G., Demaine, A., Papiha, S., Triantaphyllidis, C., Stefanescu, G., Hatina, J., Belledi, M., Di Rienzo, A., Novelletto, A., Oppenheim, A., Nørby, S., Al-Zaheri, N., Santachiara-Benerecetti, S., Scozari, R., Torroni, A., \& Bandelt, H. J. (2000). Tracing European founder lineages in the near eastern mtDNA pool. American Journal of Human Genetics, 67, 1251-1276.

Rowley-Conwy, P. (2011). Westward Ho! The spread of agriculture from Central Europe to the Atlantic. Current Anthropology, 52, S431S451. doi:10.1086/658368

Sampietro, M.L., Lao, O., Caramelli, D., Lari, M., Pou, R., Marti, M., Bertranpetit, J., Lalueza-Fox, C. (2007). Palaeogenetic evidence supports a dual model of Neolithic spreading into Europe. Proceedings of the Royal Society B, 274, 2161-2167.

doi:10.1098/rspb.2007.0465

Sherratt, A. (1981). Plough and pastoralism: aspects of the secondary products revolution. In I. Hodder, G. Isaac, \& N. Hammond (eds.), Pattern of the past: Studies in honour of David Clarke (pp. 261-305). Cambridge: Cambridge University Press.

Soares, P., Achilli, A., Semino, O., Davies, W., Macaulay, V., Bandelt, H.-J., Torroni, A., \& Richards, M. B. (2010). The archaeogenetics of Europe. Current Biology, 20, R174-R183. doi:10.1016/j.cub.2009.11.054

Tetzlaff, S., Brandstätter, A., Wegener, R., Parson, W., \& Weirich, V. (2007). Mitochondrial DNA population data of HVS-I and HVS-II sequences from a northeast German sample. Forensic Science International, 172, 218-224. doi:10.1016/j.forsciint.2006.12.016

Vander Linden, M. (2007). What linked the Bell Beakers in third millennium BC Europe? Antiquity, 81, 343-352.

Von Cramon-Taubadel, N., \& Pinhasi, R. (2011). Craniometric data support a mosaic model of demic and cultural Neolithic diffusion to outlying regions of Europe. Proceedings of the Royal Society B, 278, 2874-2880. doi:10.1098/rspb.2010.2678

Whittle, A. W. R. (1996). Europe in the Neolithic: The Creation of New Worlds. Cambridge: Cambridge University Press.

Whittle, A., \& Cummings, V. (2007). Going over: The mesolithic-neolithic transition in north-west Europe. Oxford: Oxford University Press. doi:10.5871/bacad/9780197264140.001.0001

Zvelebil, M. (2004) Who were we 6000 years ago? In search of prehistoric identities. In M. Jones (ed.), Traces of ancestry: Studies in honour of Colin Renfrew. Cambridge: McDonald Institute Monographs.

\section{Supplemental Materials}

Supplemental Movie 1. http://youtu.be/C5nijHibX3c

Dynamic illustration of mtDNA haplogroup frequencies changing through the four sampled time points.

(supplemental Tables 1-4 see the following pages) 
F.-X. RICAUT ET AL.

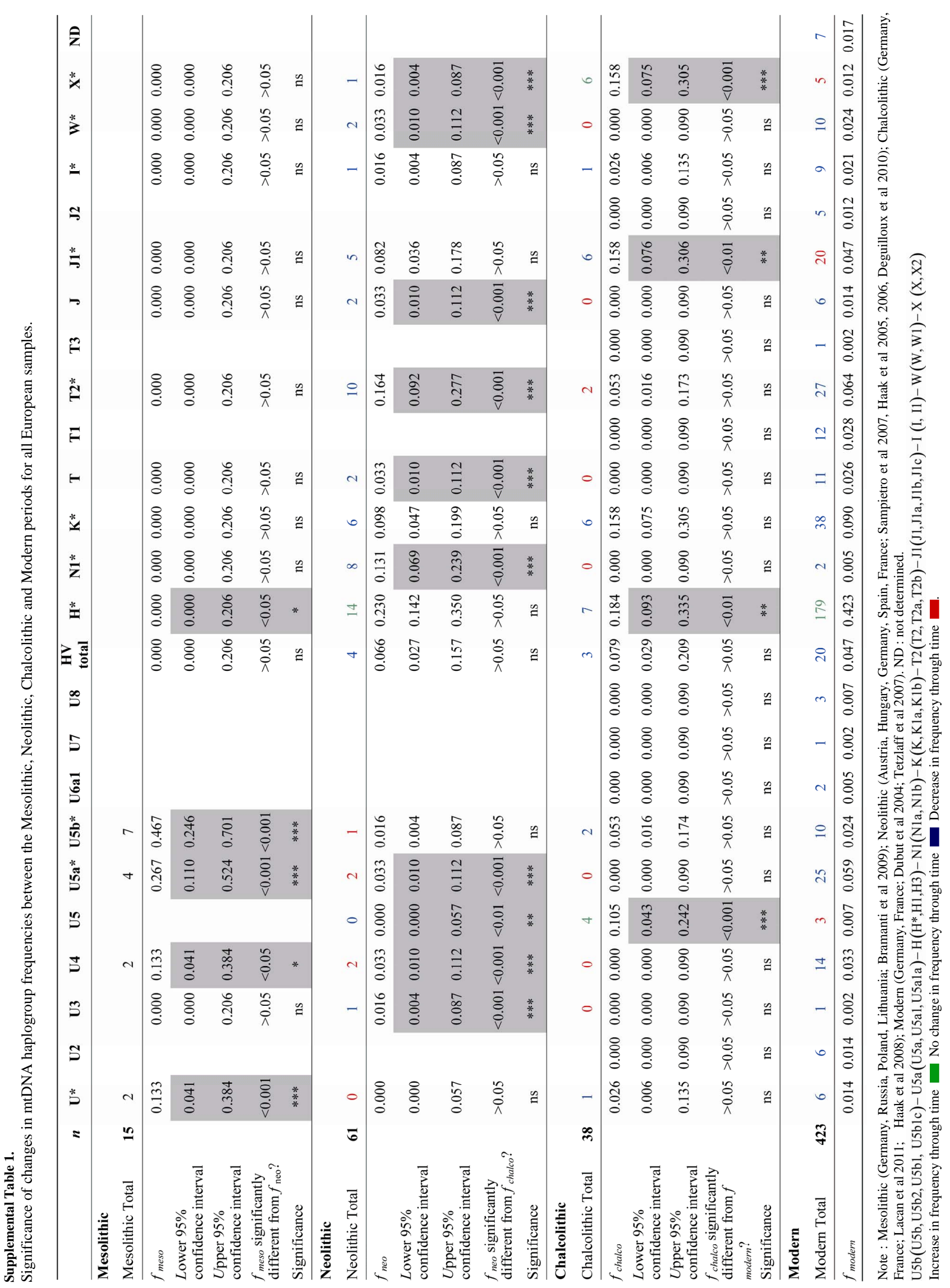


F.-X. RICAUT ET AL.

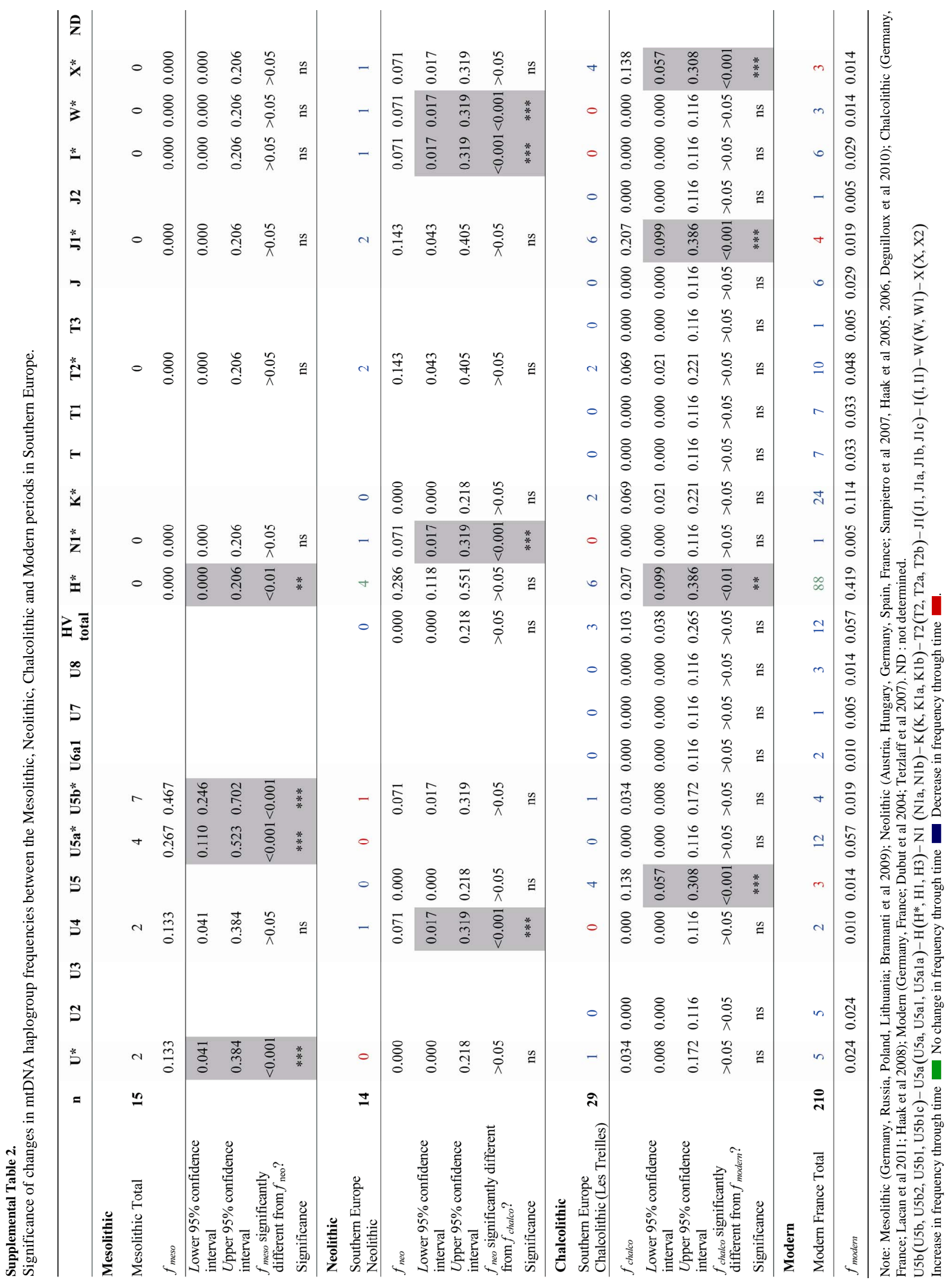


F.-X. RICAUT ET AL.

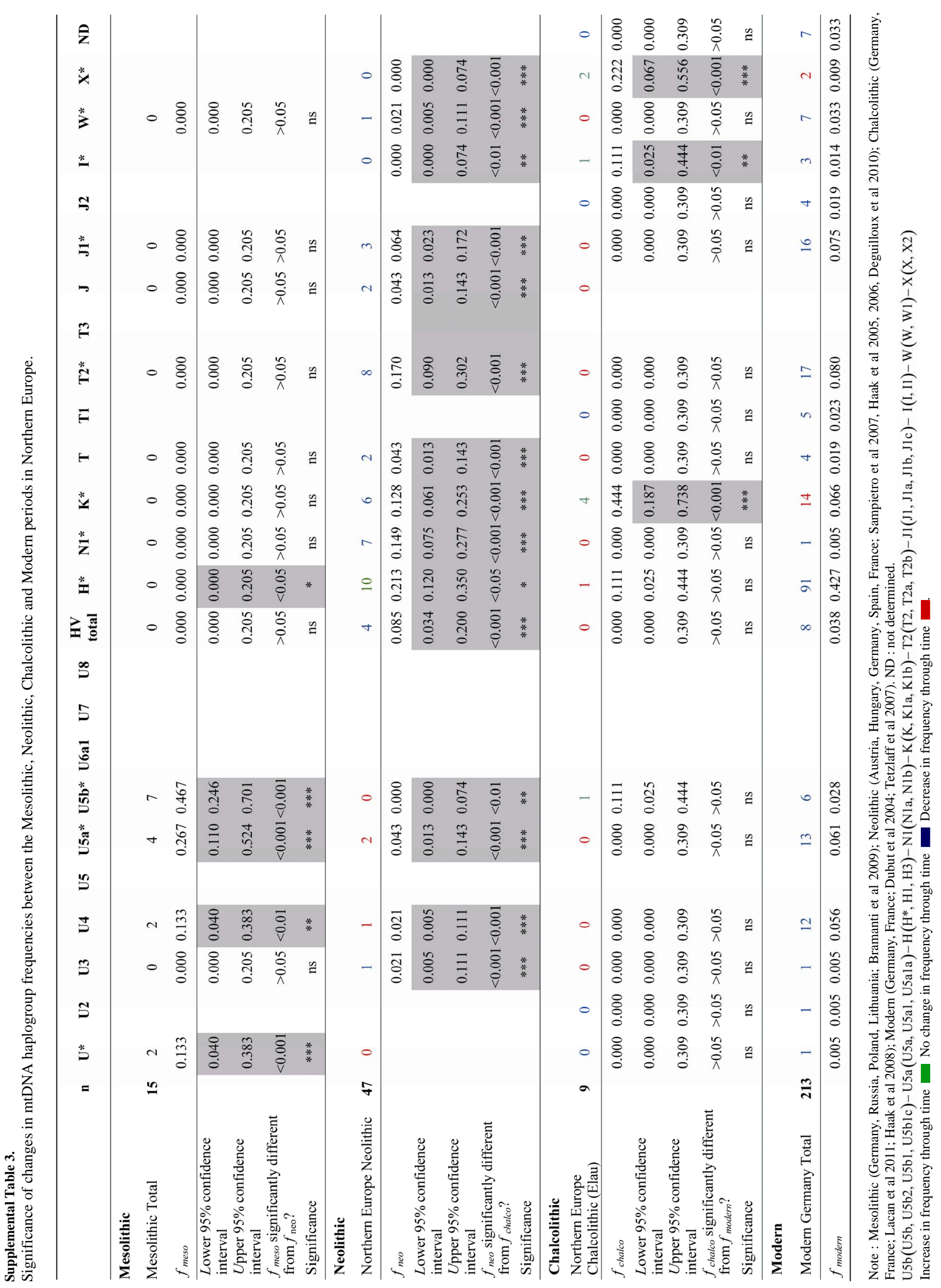


F.-X. RICAUT ET AL.

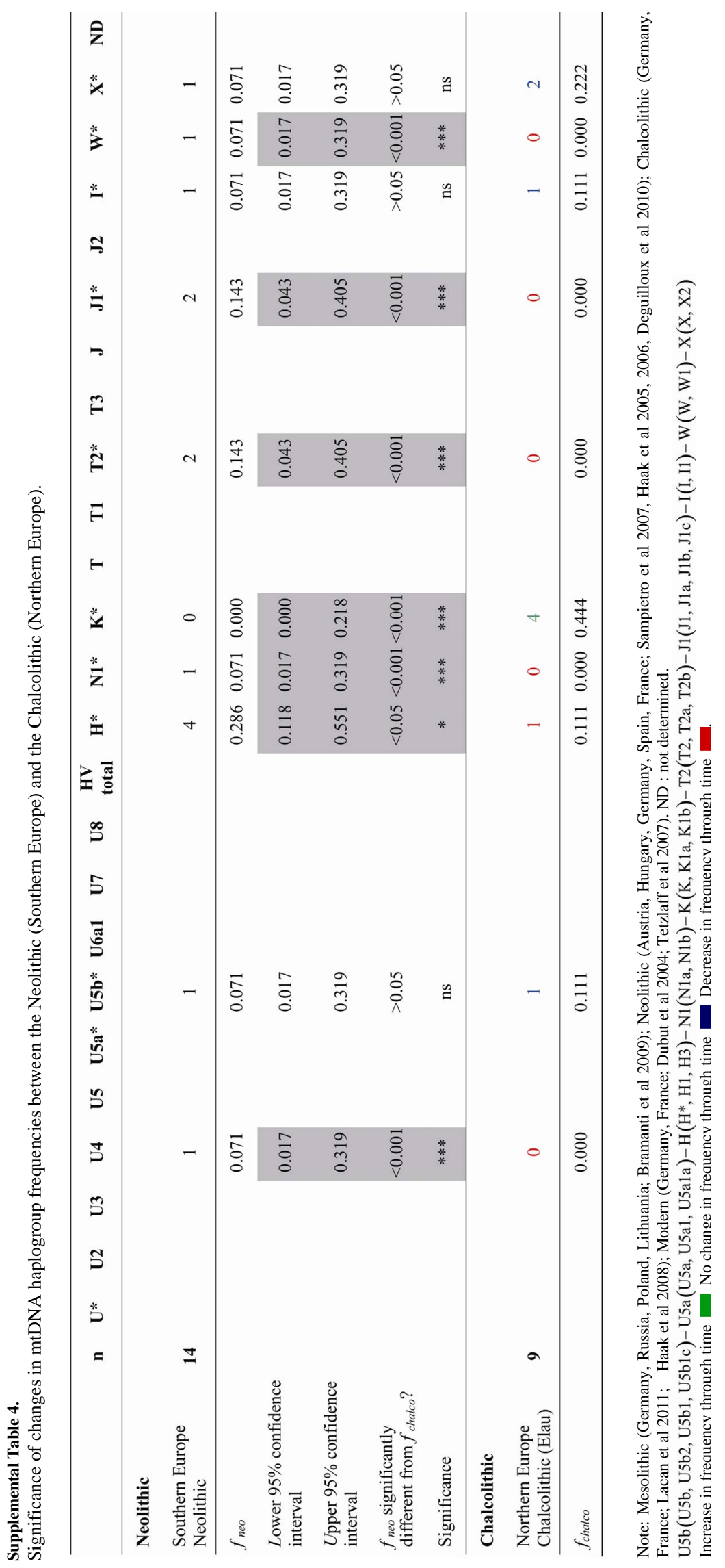

